Faculty of Agriculture, Omdurman Islamic University P.O. Box 382, Sudan

\title{
EFFECT OF DIETARY ENERGY LEVEL ON PERFORMANCE AND CARCASS QUALITY OF BROILER CHICKS
}

(With 8 Tables)

\author{
By
}

SAFA M.A. EL TAZI

(Received at 18/10/2009)

\section{SUMMARY}

The effect of various metabolizable energy level on performance and carcass quality of broiler chicks were studied. A total of one hundred and fifty one-day old, unsexed (Ross) broiler chicks were randomly divided into five experimental groups. Each group was further subdivided into five replicates at the rate of six chicks per pen in complete randomized design. The birds were fed on five levels of metablizable energy $(2827,2972,3085,3162$ and $3210 \mathrm{Kcal} / \mathrm{kg}$ ) with constant level of dietary protein $(22 \%)$ for 7 weeks duration. Health of the stock and performance parameters were recorded. At the end of the experiment, the birds were slaughtered, dressing, and used for different parameters. The results indicated that the energy level had significant $(\mathrm{P}<0.01)$ effect on performance and carcass quality of broiler chicks. Birds fed the highest energy diet $(3210 \mathrm{Kcal} / \mathrm{kg})$ showed better results in body weight gain, feed efficiency and dressing percentage with the lowest feed intake as compared to the other experimental diets. The birds fed the highest energy diet $(3210 \mathrm{~kg} / \mathrm{kg})$ had significantly $(\mathrm{P}<0.01)$ highest carcass fat content and abdominal fat percentage as compared to the other diets.

Key words: Brioler chicks, carcase quality, feed, metabolizable energy.

\section{INTRODUCTION}

The broiler chicks are known to be precisely demanding for essential nutrients in their diets, in order to express their genetic 
potentials for optimum production. Of these nutrients requirement, energy which constitutes the major entity, as it is required in larger quantities than the other nutrients and it also influences voluntary feed intake and is much related to protein, amino acids and other dietary nutrients consumption and utilization. In addition to, energy constitutes the major cost item in formulation of adequate least-cost diet for broilers and hence would affect the economic efficiency of production. However, limited local research has been conducted to determine the adequate level of dietary metabolizable energy for feeding broiler chicks under open housing system in Sudan (El-Tazi, 2001).

This study was intended to gain more information about the effect of various levels of dietary metabolizable energy on broiler performance and carcass quality in Sudan.

\section{MATERIALS and METHODS}

A total of 150 one-day old unsexed (Ross) chicks were randomly distributed into 5 groups of 30 chicks. Each group was further subdivided into 5 replicates with 6 chicks per each. The chicks of each replicate were housed in a pen (1 square meter) in an open-sided deep litter house. Five levels of metabolizable energy (2827, 2972, 3085, 3162 and $3210 \mathrm{Kcal} / \mathrm{kg}$ ) with constant dietary protein level (22\%) were fed during the experimental period for 7 weeks duration. All the experimental diets were formulated to meet the nutrient requirements of boiler chicks according to (NRC, 1994) which was formulated from the local feed ingredients commonly used for poultry feeding in the Sudan. Calculated analysis of the experimental diets was done according to feedstuff analysis outlined by Ellis (1981) while determined chemical analysis was conducted by the methods of AOAC (1988). Formulation and chemical composition of the experimental diets are shown in Tables ( 1 and 2), while the chemical composition of the super concentrate used in diets is shown in Table (3). Feed and water were offered ad-libitum. The light was continuous throughout of the experimental period. The performance of the experimental birds in term of feed intake, live weight gain and feed efficiency were recorded weekly. Health of the experimental stock and mortality rate were closely observed and recorded daily. 
Table 1: Formulation and chemical composition of the experimental diets (percent as fed)

\begin{tabular}{|l|c|c|c|c|c|}
\hline \multicolumn{1}{|c|}{$\begin{array}{c}\text { Energy level } \\
\text { (Kcal/kg) }\end{array}$} & 2827 & 2972 & 3085 & 3162 & 3210 \\
Item & & & & & \\
\hline A. Formulation & & & & & \\
Grain sorghum & 55 & 65 & 63 & 49 & 60 \\
Wheat bran & 8 & - & - & 8 & 2 \\
Groundnut meal & 10 & 11 & 13 & 15 & 10 \\
Sesame meal & 19 & 16 & 14 & 14 & 15 \\
Super concentrate & 5 & 5 & 5 & 5 & 5 \\
Oyster shell & 2.75 & 2.75 & 2.75 & 2.75 & 2.75 \\
Common salt & 0.25 & 0.25 & 0.25 & 0.25 & 0.25 \\
Vegetable oil & - & - & 2 & 6 & 5 \\
\hline \multicolumn{1}{|c|}{ Total } & 100 & 100 & 100 & 100 & 100 \\
\hline B. Chemical composition & & & & & \\
Dry matter & 97.20 & 95.90 & 96.30 & 98.00 & 98.10 \\
Crude protein (N\% x 6.25) & 22.10 & 22.21 & 22.60 & 22.31 & 22.20 \\
Ether extract & 4.23 & 4.59 & 6.86 & 7.72 & 8.42 \\
Crude fibre & 7.78 & 4.80 & 4.90 & 6.41 & 4.50 \\
Ash & 10.29 & 9.38 & 9.28 & 10.51 & 8.82 \\
Nitrogen free-extract & 49.79 & 54.92 & 52.66 & 49.00 & 53.05 \\
\hline
\end{tabular}

Table 2: Chemical composition of the experimental diets (percent as fed)

\begin{tabular}{|l|c|c|c|c|c|}
\hline \multicolumn{1}{|c|}{$\begin{array}{c}\text { Energy level } \\
\text { (Kcal/kg) }\end{array}$} & 2827 & 2972 & 3085 & 3162 & 3210 \\
\hline Item & 5.56 & 6.13 & 7.33 & 8.16 & 9.86 \\
\hline Crude fat & 22.10 & 22.12 & 22.13 & 22.12 & 22.11 \\
\hline Lysine protein & 1.01 & 1.02 & 1.03 & 1.01 & 1.00 \\
\hline Methionine & 0.40 & 0.46 & 0.47 & 0.45 & 0.46 \\
\hline Cystine & 0.30 & 0.30 & 0.30 & 0.30 & 0.30 \\
\hline Methionine + cystine & 0.30 & 0.32 & 0.33 & 0.32 & 0.30 \\
\hline Calcium & 1.00 & 1.10 & 1.30 & 1.02 & 1.00 \\
\hline Available phosphorus & 0.61 & 0.162 & 0.65 & 0.63 & 0.66 \\
\hline $\begin{array}{l}\text { Calorie-protein ration } \\
\text { (ME Kcal/kg: protein \%) }\end{array}$ & 128 & 135 & 140 & 143 & 146 \\
\hline
\end{tabular}


Table 3: Energy and chemical composition of the super concentrate used in diet formulation (Hendrix broiler concentrate)

\begin{tabular}{|l|c|}
\hline \multicolumn{1}{|c|}{ Metabolizable energy } & $1900(\mathrm{Kcal} / \mathrm{kg})$ \\
\hline Crude protein & $32.00 \%$ \\
Lysine & $11.00 \%$ \\
Methionine & $2.80 \%$ \\
Methionine + & $2.25 \%$ \\
cystine & \\
Calcium & $8.00 \%$ \\
Available phosphorus & $5.00 \%$ \\
\hline
\end{tabular}

At the end of $7^{\text {th }}$ week, the birds were individually weighed after overnight fast (except for water) and slaughtered without stunning. They were then scalded, manually plucked, washed and allowed to drain on wooden tables. Evisceration was performed by a ventral cut and visceral as well as thoracic organs were removed. After evisceration internal organ, head and shanks were removed, weighed individually and expressed as percentage of slaughtered weight. Eviscerated carcasses were weighed and then chilled in a refrigerator for 24 hours at $4^{\circ} \mathrm{C}$. Cold carcasses were recorded.

All the slaughtered birds were used for dissection. The breast, thigh and drumstick of the left side of each carcass were dislocated, weighed and expressed as percentage of cold carcass weight. After that, the breast and thigh of each carcass were deboned and minced twice and then kept frozen for determination of their chemical composition. Statistical analyses were made by analysis of variance for a completely randomized design, according to Stell and Torrie (1986).

\section{RESULTS}

The effect of various energy levels on broiler's performance is shown in Table (4). The body weight gain and feed conversion ratio were improved significantly $(\mathrm{P}<0.01)$ as the level of energy was increased, while the total feed intake tended to decreased significantly $(\mathrm{P}<0.01)$ with increasing the level of energy. The diet with the highest level of energy $(3210 \mathrm{Kcal} / \mathrm{kg})$ showed significantly $(\mathrm{P}<0.01)$ highest body weight gain and best feed conversion ratio with the lowest feed intake as compared to the other experimental diets. 
Table 4: Effect of various energy levels on the performance of broiler chicks

\begin{tabular}{|c|c|c|c|c|c|c|}
\hline Item & 2827 & 2972 & 3085 & 3162 & 3210 & SEM \\
\hline $\begin{array}{l}\text { Initial live weight } \\
\text { (g/chick) }\end{array}$ & 45.2 & 45.3 & 45.3 & 54.3 & 45.2 & - \\
\hline $\begin{array}{l}\text { Final live weight } \\
\text { (g/chick) }\end{array}$ & $1877^{\mathrm{d}}$ & $1976^{d}$ & $2030^{c}$ & $2082^{b}$ & $2110^{\mathrm{a}}$ & $6.33^{* *}$ \\
\hline $\begin{array}{l}\text { Body weight } \\
\text { gain(g/chick) }\end{array}$ & $1831.8^{\mathrm{a}}$ & $1930.7^{\mathrm{c}}$ & $1984.7^{\mathrm{c}}$ & $2036.7^{b}$ & $2064.8^{\mathrm{a}}$ & $6.32^{* *}$ \\
\hline $\begin{array}{l}\text { Total feed intake } \\
\text { (g/chick) }\end{array}$ & $4213.1^{\mathrm{a}}$ & $4189.6^{\mathrm{b}}$ & $4167.8^{c}$ & $4073.4^{\mathrm{d}}$ & $3923.1^{\mathrm{e}}$ & $10.3^{* *}$ \\
\hline $\begin{array}{l}\text { Feed conversion } \\
\text { ration }\end{array}$ & $2.30^{\mathrm{a}}$ & $2.17^{\mathrm{b}}$ & $2.10^{\mathrm{b}}$ & $2.00^{c}$ & $1.90^{\mathrm{d}}$ & $0.006^{* * *}$ \\
\hline
\end{tabular}

SEM: Standard error of the means

**: Highly significant $(\mathrm{P}<0.01)$

Means within each treatment row of the same superscripts are not significant different $(\mathrm{P}>0.05)$.

With regard to NRC (1994) it can be noticed that, all the experimental diets stimulated adequate nutrient intake at all levels of energy (Table 5).

Table 5: Feed and nutrient intake of the experimental diets (g/chick)

\begin{tabular}{|l|c|c|c|c|c|c|}
\hline $\begin{array}{r}\text { Energy level } \\
\text { Item }\end{array}$ & $\begin{array}{c}\text { NRC } \\
(1994)\end{array}$ & 2827 & 2972 & 3085 & 3162 & 3210 \\
\hline Feed intake & - & 4213.1 & 4189.6 & 4167.8 & 4073.4 & 3923.1 \\
\hline $\begin{array}{l}\text { Metabolizable } \\
\text { energy intake } \\
\text { (Kcal/chick) }\end{array}$ & 8750 & 11153 & 11650 & 11735 & 12503 & 12900 \\
\hline Protein intake & 693 & 995 & 960 & 933 & 929 & 920 \\
\hline Lysine & 34.4 & 45.6 & 45.4 & 45.2 & 45.2 & 45.1 \\
\hline $\begin{array}{l}\text { Methionine }+ \\
\text { cystine }\end{array}$ & 23.9 & 36.5 & 36.2 & 33.9 & 33.2 & 30.5 \\
\hline
\end{tabular}


Table (6) shows the effect of dietary energy level on carcass characteristic of the broilers. There was no significant difference $(\mathrm{P}>0.05)$ in all the parameters measure except the hot and cold eviscerated carcass weights. Birds fed diet with the highest level of energy $(3210 \mathrm{Kcal} / \mathrm{kg})$ gave significantly $(\mathrm{P}<0.01)$ heavier hot and cold eviscerated carcass weights, while those fed diet with the lowest level of energy $(2827 \mathrm{Kcal} / \mathrm{kg})$ gave the lightest values

Table 6: Means-values for the dressing carcass percentage and commercial cuts of broiler carcasses

\begin{tabular}{|l|c|c|c|c|c|c|}
\hline $\begin{array}{r}\text { Energy level } \\
(\text { Kcal/kg) }\end{array}$ & 2827 & 2972 & 3085 & 3162 & 3210 & SEM \\
\hline Item & $1311.3^{\mathrm{e}}$ & $1380.7^{\mathrm{d}}$ & $1409.7^{\mathrm{c}}$ & $1445.1^{\mathrm{b}}$ & $1487.2^{\mathrm{a}}$ & $19.3^{* *}$ \\
\hline $\begin{array}{l}\text { Hot eviscerated carcass } \\
\text { weight (g/chick) }\end{array}$ & $1286.1^{\mathrm{e}}$ & $1347.6^{\mathrm{d}}$ & $1377.3^{\mathrm{c}}$ & $1417.6^{\mathrm{b}}$ & $1457.2^{\mathrm{a}}$ & $18.7^{* *}$ \\
\hline $\begin{array}{l}\text { Cold eviscerated carcass } \\
\text { weight (g/chick) }\end{array}$ & 69.5 & 69.5 & 69.6 & 69.8 & 70.1 & $0.17^{\mathrm{NS}}$ \\
\hline Dressing percentage & 26.2 & 26.4 & 26.7 & 26.8 & 26.9 & $0.05^{\mathrm{NS}}$ \\
\hline $\begin{array}{l}\text { Breast as (\%) of cold } \\
\text { carcass }\end{array}$ & 15.7 & 15.6 & 15.5 & 15.3 & 15.1 & $0.02^{\mathrm{NS}}$ \\
\hline $\begin{array}{l}\text { Drumstick as (\%) of } \\
\text { cold carcass }\end{array}$ & 17.9 & 17.6 & 17.5 & 17.4 & 17.2 & $0.03^{\mathrm{NS}}$ \\
\hline $\begin{array}{l}\text { Thigh as (\%) of cold } \\
\text { carcass }\end{array}$ & & & & & \\
\hline
\end{tabular}

SEM: $\quad$ Standard error of the means

**: $\quad$ Highly significant $(\mathrm{P}<0.01)$

NS: $\quad$ Means not significant $(\mathrm{P}>0.05)$.

Table (7) shows the effect of various energy levels on the noncarcass components as a percentage of body weight. There was no significant difference $(\mathrm{P}>0.05)$ in the percentage of total viscera, liver, heart, gizzard and head and shanks except the abdominal fat percentage. Birds fed diet with highest energy level (3210 Kcal/kg) gave significantly $(\mathrm{P}<0.01)$ the highest abdominal fat percentage while those fed diet with the lowest energy level $(2827 \mathrm{Kcal} / \mathrm{kg})$ gave the lowest of these values. 
Table 7: Body weight and organ proportions of broiler chickens

\begin{tabular}{|l|l|l|l|l|l|l|}
\hline $\begin{array}{r}\text { Energy level } \\
\text { (Kcal/kg) }\end{array}$ & 2827 & 2972 & 3085 & 3162 & 3210 & SEM \\
\hline $\begin{array}{l}\text { Final body weight } \\
\text { (g/chick) }\end{array}$ & $1877^{\mathrm{e}}$ & $1976^{\mathrm{d}}$ & $2030^{\mathrm{c}}$ & $2082^{\mathrm{b}}$ & $2110^{\mathrm{a}}$ & $6.33^{* *}$ \\
\hline $\begin{array}{l}\text { Total viscera as (\%) of } \\
\text { body weight }\end{array}$ & 8.05 & 8.03 & 8.03 & 8.07 & 8.03 & $0.016^{\mathrm{NS}}$ \\
\hline $\begin{array}{l}\text { Abdominal fat as (\%) } \\
\text { of body weight }\end{array}$ & $1.73^{\mathrm{e}}$ & $1.81^{\mathrm{d}}$ & $1.95^{\mathrm{c}}$ & $2.01^{\mathrm{b}}$ & $2.23^{\mathrm{a}}$ & $0.03^{* *}$ \\
\hline $\begin{array}{l}\text { Liver as (\%) of body } \\
\text { weight }\end{array}$ & 2.01 & 2.06 & 2.03 & 2.01 & 2.02 & $0.02^{\mathrm{NS}}$ \\
\hline $\begin{array}{l}\text { Heart as (\%) of } \\
\text { bodyweight }\end{array}$ & 0.56 & 0.57 & 0.56 & 0.53 & 0.54 & $0.013^{\mathrm{NS}}$ \\
\hline $\begin{array}{l}\text { Gizzard as (\%) of body } \\
\text { weight }\end{array}$ & 2.02 & 2.03 & 2.04 & 2.06 & 2.03 & $0.06^{\mathrm{NS}}$ \\
\hline $\begin{array}{l}\text { Head and shanks as } \\
\text { (\%) of body weight }\end{array}$ & 6.51 & 6.52 & 6.53 & 6.56 & 6.58 & $0.016^{\mathrm{NS}}$ \\
\hline
\end{tabular}

SEM: Standard error of the means

**: $\quad$ Highly significant $(\mathrm{P}<0.01)$

NS: Means not significant $(\mathrm{P}>0.05)$.

Table (8) shows the effect of various energy levels on the chemical composition of breast and thigh muscles of broilers. There was no significant difference $(\mathrm{P}>0.05)$ in the percentages of protein, ash and moisture for both breast and thigh muscles of the broiler among the experimental treatments except the fat percentage for both breast and thigh muscles. Birds fed diet with the highest energy level (3210 $\mathrm{Kcal} / \mathrm{kg}$ ) produced significantly $(\mathrm{P}<0.01)$ highest carcass fat percentage while those fed diet with the lowest energy level (2827 Kcal/kg) produced the lowest values. 
Table 8: Chemical composition of breast and thigh muscles of broiler chicks

\begin{tabular}{|c|c|c|c|c|c|c|}
\hline $\begin{array}{r}\text { Energy level } \\
(\text { Kcal/kg) }\end{array}$ & 2827 & 2972 & 3085 & 3162 & 3210 & SEM \\
\hline Item & & & & & & \\
Freast $\%$ & $10.73^{\mathrm{d}}$ & $11.52^{\mathrm{c}}$ & $12.13^{\mathrm{b}}$ & $12.90^{\mathrm{b}}$ & $14.49^{\mathrm{a}}$ & $0.33^{* *}$ \\
Protein \% & 23.02 & 22.92 & 22.26 & 22.11 & 22.05 & $0.30^{\mathrm{NS}}$ \\
Moisture \% & 62.18 & 62.36 & 62.20 & 62.71 & 62.50 & $0.15^{\mathrm{NS}}$ \\
Ash \% & 2.06 & 2.05 & 2.02 & 2.06 & 2.04 & $0.15^{\mathrm{NS}}$ \\
\hline Thigh & & & & & & \\
Fat \% & $11.67^{\mathrm{d}}$ & $12.24^{\mathrm{c}}$ & $13.56^{\mathrm{b}}$ & $13.91^{\mathrm{b}}$ & $16.25^{\mathrm{a}}$ & $0.43^{* *}$ \\
Protein \% & 22.03 & 22.51 & 22.13 & 22.03 & 22.00 & $0.33^{\mathrm{NS}}$ \\
Moisture \% & 63.71 & 63.56 & 63.66 & 63.91 & 63.31 & $0.13^{\mathrm{NS}}$ \\
Ash \% & 1.63 & 1.72 & 1.64 & 1.55 & 1.65 & $0.16^{\mathrm{NS}}$ \\
\hline
\end{tabular}

SEM: Standard error of the means

** : Highly significant $(\mathrm{P}<0.01)$

Means within each treatment row of the same superscripts are not significant different $(\mathrm{P}>0.05)$

NS: Means not significant $(\mathrm{P}>0.05)$.

The experimental treatments had no significant $(\mathrm{P}>0.05)$ effect on the mortality rate. Only one bird from each treatment died, which cannot be related in any way to the experimental treatments.

\section{DISCUSSION}

The effect of feeding various levels of metabolizable energy on the productive performance of broiler is shown in Table (4). Treatment effect on body weight gain, fed intake and fed efficiency was highly significant $(\mathrm{P}<0.01)$. Birds fed diet contained $3210 \mathrm{Kcal} / \mathrm{kg}$ metabolizable energy produced significantly $(\mathrm{P}<0.01)$ the heaviest body weight gain and the lowest feed consumption with the best feed utilization efficiency as compared to other experimental diets. The experimental birds tended to adjust their feed intake according to the dietary energy level by eating less from the high energy diets. The highest body weight gain and the best feed utilization efficiency were attained by the diet containing the highest level of energy. These effects were consistent with the increased nutrients intake from the different experimental diets (Table 5). The experimental birds consumed progressively more energy from the higher energy diets, in spite of the general depressing effect of the dietary energy level on feed 
consumption. These results are agreement with those reported by Sadagopan et al., (1971); Salmon et al., (1983) and El-Tazi (2001). The result coincided with the finding of Proudfoot and Hulan (1987) who mentioned that the highest dietary energy $(3100 \mathrm{Kcal} / \mathrm{kg}$ ) gave the highest growth rate, the highest profit and the most efficient feed conversion as compared to the lowest energy diet $(2900 \mathrm{Kcal} / \mathrm{kg})$. Similar results have been obtained by Bertechini et al., (1991) who stated that, there was a linear increase in weight gain and a decrease in feed intake as the energy intake was increased.

As shown in Table (6), the dressing percentages on hot and cold carcass base were highly significantly $(\mathrm{P}<0.01)$ increased with increasing energy level. These results are consistent with the differences in growth rate and the subsequent final live weight on the different experimental diets. Similar results have been obtained by Preston and William (1973) who indicated that heavier birds at slaughter would have greater dressing percentage and higher eviscerated yield than lighter birds. These results were in line with the findings of El-Tazi et al., (1990) who mentioned that, the increased eviscerated yield obtained from birds that were fed free choice method with unground grains might be due to the heavier slaughter weight.

As shown in Table (7), the percentage of abdominal fat was increased significantly $(\mathrm{P}<0.01)$ with increasing the level of energy. Birds fed diet that contained $3210 \mathrm{Kcal} / \mathrm{kg}$ produced the highest percentage of abdominal fat while birds fed diet contained $2827 \mathrm{Kcal} / \mathrm{kg}$ produced the lowest percentage values. Thee results are in agreement with those reported by Salmon et al., (1983) and El-Tazi, (2001). Similar results were obtained by Motozonon et al., (1998) who indicating that, abdominal fat of broilers would increase with increasing dietary energy concentration. This dietary effects on abdominal fat deposition are basically associated with the utilization efficiency of nutrients for energy production and lipogensis.

As shown in Table (8), the chemical composition of the breast and thigh muscles confirms the effect of increasing the energy level which increasing the fat content of the carcasses. Birds fed diet contained $3210 \mathrm{Kcal} / \mathrm{kg}$ metabolizable energy produced the highest carcass fat content while those fed diet contained $2827 \mathrm{Kcal} / \mathrm{kg}$ energy gave the lowest values. These results were in line with other findings Pesti and Fletcher (1983); Salmon and Torrie (1986) and El-Tazi (2001). Who reported that increased metabolizable energy level would result in an increased carcass fat deposition. 


\section{REFERENCES}

AOAC (1988): Official methods of analytical (12 ${ }^{\text {th }}$ ed) Association of Official Analytical Chemists, Washington D.C., USA.

Bertechini, A.G.; Rostagno, H.S.; Soares, P.R.; Oliveira, A.I.G de and De-Oliveira, A.I.G. (1991): Effect of varying energy intake during starting and finishing periods on performance and carcass quality of broiler fowls. Revista-da-SociedadeBrasileira-de-Zootecnia, 20: 3, 241-249.

El-Husseini, S.M.; Shalash, and Azouz, H.M. (2002): Response of broiler performance to diets containing hot pepper, and or fenugreek at different metabolizable energy levels. Egyptian Poultry Sci. Journal, Vol. 22 (11): 387-406.

Ellis, N. (1981): The nutrient composition of Sudanese animal feeds. Bulletin, 1: Northern and Central Sudan, Central Animal Nutrition Research Laboratory, Kuku Research Centre, Khartoum North, Sudan.

El-Tazi, S.M.A. (2001): The effect of dietary energy and protein utilization on performance and carcass quality of broiler chicken under Sudan condition. Ph.D. Thesis, University of Khartoum, Sudan.

El-Tazi, S.M.A.; Tibin, I.M. and El Tayeb, A.E. (1990): Feeding different feed forms to broiler during the finishing period. Effect on performance carcass traits and non-carcass components. The Sudan Journal of Animal Production, 3 (1): 27-35.

Motozonon, Y.; Hatano, K.; Sugawara, N. and Ishibashi, T. (1998): Effects of dietary calorie: protein ratio on abdominal fat accumulation in female broilers. Animal Science and Technology, 69 (7): 666-672.

NRC (National Research Council) (1994): Nutrient requirements of poultry. $9^{\text {th }}$ Rev. ed National Academy Press, Washington, DC.

Pesti, G.M. and Fletcher, D.L. (1983): The response to male broiler chickens to diets with various protein and energy content during the growing phase. British Poult. Sci., 24 (1): 91-99.

Preston, L.H. and William, W.M. (1973): Eviscerated yield, component parts and meat, skin bone ratios in chicken broiler, Poult. Sci., 52: 718-722.

Proudfoot, F.G. and Hulan, H.N. (1987): Interrelationships among lighting ambient temperature and dietary energy and broiler chicken performance. Poult. Sci., 66 (11): 1744-1749. 
Sadagopan, V.R.; Base, S. and Pal, K.K. (1971): Studies on determination of optimum metabolizable energy: protein ratio of poultry ration for growth and feed efficiency in white leghorn birds. Indian Vet. Flour. 48 (6): 614-624.

Salmon, R.E.; Classen, H.L. and McMillan, RY. (1983): Effect of starter and finisher protein on performance, carcass grade and meat yield of broiler. Poult. Sci., 62: 837.

Steel, R.G.D. and Torrie, J.H. (1986): Principles and procedures of statistics: A Biometrical Approach ( $2^{\text {nd }}$ ed.) McGraw Hill Book Company, Inc. NY, USA. 
Assiut Vet. Med. J. Vol. 56 No. 124 January 2010 